\title{
Factors Contributing for Livestock Excessive Mortality in Borana Pastoralist Area: Signal for Leadership and Disaster Risk Management Policy of Ethiopia
}

\author{
Petros Wako* Neng Shen ${ }^{* *}$ \\ Huazhong University of Science and Technology, School of Public Administration, Department of \\ Administrative Management, P.O box 430074, Wuhan ,China
}

\begin{abstract}
Livestock production is one of major mainstay in pastoralist area. In order to keep its livestock, pastoralist applies traditional drought coping mechanism. Currently Government of Ethiopia addressing drought disaster in the area of pastoralist by implementing disaster risk reduction management policy. However there are excessive livestock mortality in pastoralist area of Ethiopia specially Borana. The objective of this paper is to find out factors contributing for excessive livestock mortality in the pastoralist area and analyze its signals for Ethiopian National disaster risk management policy implementation of pastoralist areas. The main data for this research come from primary and secondary sources. The research use mixed method to collect and analyze data. Data collecting tools were questionnaire, key informant interview, focused group discussion, observation and document review. The finding of the study portray that lack of awareness of pastoralist to manage the quality of livestock, lack proper attention for pastoralist, lack of animal health facilities in the adjacent area of pastoralist production, outbreak of livestock disease, inadequate pasture land because of expansion of farming land and tribal conflict, failure of traditional coping mechanisms such as mobility, failure of early warning system and absence of livestock marketing in the pastoralist area are contributing for excessive livestock mortality in the area. This research conclude that current disaster risk management policy implementers and leadership able to consider the extension works intensively to raise the awareness of the community to sell their livestock before serious drought period, due attention for causes of pastoralists and pastoralist centered policy, expand animal health facilities in relation with livestock population, deploy necessary animal health technician in the area, introduce and increase vaccination, support traditional coping mechanisms, work on tribal conflict prevention and intervene by proper and just livestock marketing.
\end{abstract}

Keywords: Borana, Leadership, Disaster, Livestock, Pastoralist, Policy

DOI: $10.7176 /$ PPAR/10-2-04

Publication date: February $29^{\text {th }} 2020$

\section{Introduction}

Ethiopian has a lot of number of livestock in the world. Ethiopia is thought to have principal livestock population in Africa. The world rank of Ethiopian livestock number is around 10 and it's $1^{\text {st }}$ in the African continent. In pastoralist areas of Ethiopia people are highly dependent on the livestock and livestock products. Mainly this is because of arid and semi-arid environment made erratic in rain distribution. Land use planning indicate that most of area those pastoralists living are not suitable for other agricultural activities. Domestic animals sector has been contributing significant portion to the economy of the country (FAO, 1995).

The lowlands, commonly reflected to as "pastoral areas "are found in the Eastern, South Eastern and Southern parts of the country. In reference to the administrative structure, these are largely the Afar, Somali, Borana in Oromia Region and Omo Valley in the SNNP Region. The Ethiopian pastoral areas are projected to occupy about $61-65 \%$ of the total area of the country and are home to $12-13 \%$ of the total population. As a result, out of the total estimated livestock population of the country, the pastoral areas comprise approximately $30 \%$ of the cattle, $52 \%$ of the sheep, $45 \%$ of the goats and $100 \%$ of the camels (Beruk Y., 2003).

The livestock capitals are the main continuation base for the people, resource potentials opening for intervention by the private sector. Livestock in the pastoral areas are the major source of food such as milk and meat as well as income a source of employment (Beruk Y., 2003)

Livestock herding is commonly practiced in Borana, which normally falls in two categories. One is homebased herding, which involves the herding of milking cattle with calves and small stock close to the encampments. The herds in this category are usually referred to as worra. The other is satellite herding, including bulls and immature stock herded further away from the encampments. This group of herds is known as forra. They usually range more widely and have access to better forage (Dika, G., 2016).

There are incredibly great populations of a variety of livestock type in the pastoral areas of Ethiopia, but there is only uneven ballpark figure of the size of these populations. The wandering livestock production system is vulnerable to even minor environmental hazards. Proper livestock policies request to be designed for the nomadic areas as the pastoralists convey on the livestock population and due to susceptibility to hazards (Beruk 
Y., 2003). This emphasize that any policy implemented in the pastoralist area expected to focus on livestock.

Marko (2012) in his study of Drought Contingency Planning emphasized that a drought management in pastoralist area not integrating the prevention and response with early warning of drought as well as development. On the top of this, Desta and Coppock (2004) studied the Pastoralist under Pressure: Tracking system Change in Southern Ethiopia and reported that drought is pressurized Borana pastoralist by causing 35$37 \%$ loss of livestock inventory that could be hundreds of millions of USD from 1980-2000.

Borana cattle production highly depends on the natural resources, which are to a great extent disturbed by recurrent drought. While natural pastures are the chief feed source for Boran cattle pasture productivity has recently declined and resulted in high livestock mortality (Catley et al., 2014).

Whenever there is a drought in Borana pastoralist area: the pastoralist lost their livestock incalculably. Even though, the community has traditional coping mechanism that enable the people to overcome the impacts of the drought because various reason; traditional coping mechanisms unable to prevent excessive livestock mortality. In line with this, identifying possible factors could contribute to minimize the excessive livestock mortality. This also expected to alert policy implementers and leadership of the area.

Ethiopian National Disaster Risk Management Policy focuses on pre disaster mitigation and prevention, response during disaster as well as recovery post drought. By taking this into consideration this paper focused on status of implementation and leadership of Disaster Risk Management Policy of Ethiopia in relation to the excessive livestock mortality in Borana pastoralist area. The research also elaborates the contributing factors for excessive livestock mortality in the area.

\section{Description of the Study Area \\ 2.1 Borana Zone}

This study was conducted in a Borana zone in the Oromia region which is found in the southern part of Ethiopia bordering Kenya. The zone is divided into thirteen districts and the capital city of the zonal town Yabello is found at a distance of $570 \mathrm{KM}$ South of Addis Ababa. The zone is bordered in the south by Kenya, in the west and north by the Southern Nations, Nationalities, and Peoples Regional State (SNNPRS), in the Southeast by Somali region and in the east by Guji zone. From total districts Dillo,Guchi,Wacille,Elwayye,Dubluki and Dhas are classified as pure pastoralists, districts including Moyale, Miyo, Dire, Yabello, Arero, Gomole and Teltele, are classified as agro-pastoralists. But, within agro-pastoral districts there are kebeles which are considered as pure pastoralists. The rainfall pattern of the zone is bimodal. The main rainy season is locally called 'Ganna' from March to May which is expected to cover $60 \%$ and the small rain season is 'Hagaya' from September to November that covers $40 \%$ with average annual rainfall of $500 \mathrm{~mm}$. The mean annual temperature varied from 19 ${ }^{0} \mathrm{c}$ to $24{ }^{\circ} \mathrm{c}$ (BZFED, 2019).

Based on the Census conducted by the Central Statistical Agency of Ethiopia (CSA, 2007), the Borana Zone has a total population of 962,489 , of whom 487,024 are men and 475,465 women with an area of 45,434.97 square kilometers, Borana has a population density of 21.18.

\subsection{Topography}

Borana pastoralist area is located between $4-6{ }^{\circ} \mathrm{N}$ and $36-42^{\circ} \mathrm{E}$. The landscape is slopes gently from the northwest to the southeast between altitude of $1500 \mathrm{~m}$ and $1000 \mathrm{~m}$ above sea level with more or less on even slope with no much up and downs.

\subsection{Climatic Condition}

Borana pastoralist area is mainly characterized by arid and a semiarid climatic condition except some pocket areas with relatively humid condition. According to report of pastoralist Development Commission of Oromo (2019) the mean annual temperature varied from 19-25 degree Celsius with slight seasonal variation. The total amount of rainfall is ranging from $400 \mathrm{~mm}-700 \mathrm{~mm}$.

The rainfall pattern of the zone is bimodal. The main rainy season is locally called 'Ganna' from March to May which is expected to cover $60 \%$ and the small rain season is 'Hagaya' from September to November that covers $40 \%$ with average annual rainfall of $500 \mathrm{~mm}$. The lowland parts are severely affected by recurrent drought as rainfall pattern is erratic.

\subsection{Livelihood of Pastoralist}

Animal husbandry is the commonly practiced old age economic system as ecological setting of Borana pastoralist area is more suitable for animal rearing than for crop cultivation (Angasa and Oba, 2007). In addition to this, Borana pastoralists keep various livestock types such as cattle, goats, sheep, camel, and equines. Moreover, cattle keeping is more preferable practiced than others animals. This is because of cattle considered as valuable asset that enrich social value. 


\subsection{Gada System as Regulatory of Socio-Economic Activities}

In Borana pastoralist the Gada system is the main social structure which is a complex, elaborate and all embracing social institution. This system generally deals with the relations within and between the generations. And more fundamentally, it is about how the Borana should live their lives. The use of existing grazing lands and water resources, and mobility of people and livestock in normal or in periods of disaster is governed by the Gada system. It also plays a large role in political affairs and conflict management and resolution (Asmarom, 1973)

The old traditions of sharing in Borana ("Buusa Gonofa") have a profound impact in making poor households less vulnerable to drought. "Buusa Gonofa" is a social security system whereby people of same clan member contribute in various ways to those highly affected and vulnerable to natural calamities like drought, conflict and disease. The contribution types and rates are determined voluntarily by the contributors but sometimes also decided by the clan leaders or elders. The contribution can consist of for instance animals or fodder. If anybody denies that decision, he will be penalized and the strong social sanction will be applied to him. The head or the leader of the Gada system is locally known as "Aba Gada" (Asmarom, 1973).

\section{Factors contributing to the excessive livestock mortality in pastoralist area}

As Solomon and his associates(2008) studied and noted that livestock dies more quickly, more regularly, and larger in numbers in this area in response to dry or drought years compared to what experienced in previous generations. Since livestock is wholesome for pastoralist, identifying the factors that contributing for immense deaths of livestock in pastoralist area are very basic. However the disaster risk management policy implementation main aims to minimize this livelihood deterioration that has wider impacts. As finding of study illustrates that some of the factors described as follows.

\subsection{Quantitative Analysis}

\section{Comparison among the strata}

Table 1. Kruskal Wallis Test about livestock population pressure, early warning, resistance of pastoralist and untimely response

\begin{tabular}{|c|c|c|c|c|}
\hline Factors & median & $\mathrm{X} 2$ & Df & $\begin{array}{l}\mathrm{p}- \\
\text { value }\end{array}$ \\
\hline There is livestock population pressure in the area & 4 & 1.784 & 3 & 0.618 \\
\hline Existing early warning is not working & 4 & 6.707 & 3 & 0.082 \\
\hline $\begin{array}{l}\text { The resistance of the pastoralist to sell their livestock before the } \\
\text { drought }\end{array}$ & 4 & 10.800 & 3 & 0.013 \\
\hline Because of untimely response & 4 & 7.193 & 3 & 0.066 \\
\hline
\end{tabular}

Source: own computation, 2019

The response is from 1 to 5 where 1 represents strongly disagree and 5 represents strongly agree

As it is clear from Table 1 regarding the livestock population pressure as contributing factor for livestock death, the median score 4 indicates that livestock population pressure on the Borana pastoralist area is factors contributing for livestock population deaths. This implies that when more livestock is there in the pasture land, there is a competition on the uses of resources. Since resource such as water and fodder are scant large number livestock death might occur. The similarity in agreement is has no statistically significant difference among yabello zonal, Moyale, Moyo and Dire woreda leaders as indicated by the result of the kruskal wallis test at $(\mathrm{P}=0.618, \mathrm{df}=3$ and $\mathrm{P}>0.05)$. From this it seems leaders having different level of administration have no difference in considering livestock population pressure as factor contributing for livestock death in Borana pastoralist area.

Regarding the existing early warning the median score of 4 shows that agreement of respondents to the failure of early warning as factor for livestock death. From this one can infer that when early warning not warning the pastoralist through dissemination of forecasts, in line with this pastoralist do not exact manage their livestock during drought that cause immense livestock deaths. The result of kruskal wallis test at $(\mathrm{P}=0.082, \mathrm{df}=3$ and $\mathrm{P}>0.05$ ) indicate that there is no statistically significant response different among the Yabello zonal, Moyale, Miyo and Dire woreda leaders on above statements. This may seem having different level of administration and place work in borana pastoralist area no difference towards the above statement.

Likewise, on the table 1 of above the median score of 4 shows that respondent's agreement on the factors contributing of livestock death as resistance of pastoralist to sell livestock before drought. This indicates that attitude of pastoralist to sell their livestock is contributing for immense livestock deaths. This may originated from the attachment of livestock to the values of pastoralist and absence of external exposures. Similarity in agreement as statistically significant as indicated by kruskal wallis test at $(\mathrm{P}=0.013, \mathrm{df}=3$ and $\mathrm{P}<0.05)$. This is evident that shows that extent of positive response varies with level of administration and place work.

To add up, concerning untimely response as factor contributing for livestock death, the median score 4 
shows agreement of the respondents. This indicate that because untimely responses livelihood of deteriorating during drought. From this it is clear that during drought livestock needs fodder and water scant. Based on this if timely response for livestock that address fodder and water there is possibility of loss. The kruskal wallis test at $(\mathrm{p}=0.066, \mathrm{df}=3$ and $\mathrm{P}>0.05)$ also shows that is nonexistence statistically significant difference among the Yabello, Moyale, Miyo and Dire leaders. This may seems having different level of administration and place work in Borana pastoralist area has no difference towards the above statements.

Table 2. Kruskal Wallis test about outbreak of disease, lack animal health, Inadequacy of pasture land and livestock marketing

\begin{tabular}{|l|l|l|l|l|}
\hline Factors contributing for livestock deaths & median & $\mathrm{X}^{2}$ & $\mathrm{df}$ & $\mathrm{p}$-value \\
\hline Outbreak of disease during drought & 4 & 4.503 & 3 & 0.212 \\
\hline Lack of animal health facilities & 4 & 4.423 & 3 & 0.219 \\
\hline Inadequacy of pasture land & 4 & 8.580 & 3 & 0.035 \\
\hline Lack of marketing that make low livestock price during drought & 4 & 3.273 & 3 & 0.351 \\
\hline The traditional coping mechanism is not working & 4 & 6.094 & 3 & 0.107 \\
\hline Lack of awareness of the pastoralist & 4 & 5.018 & 3 & 0.170 \\
\hline
\end{tabular}

Source: own computation, 2019

The response is from 1 to 5 where 1 represents strongly disagree and 5 represents strongly agree

As it is observed on the table 2 concerning the outbreak of livestock disease as factor contributing for livestock death the median value of 4 shows the agreement of respondents on the idea. This indicates that outbreaks of animal disease are contributing for livestock death in pastoralist area during drought period. This might originated from absence of proper vaccination and lack of animal health technician at livestock production area. The kruskal wallis test at $(\mathrm{p}=0.212$, df $=3$ and $\mathrm{P}>0.05)$ depict that there is no significant response difference among the independent sample groups. On the lack of animal health facility as factor contributing for livestock death, the median score of 4 indicate the agreement of respondents on the factors.

The kruskal Wallis test at $(\mathrm{p}=0.219, \mathrm{df}=3$ and $\mathrm{P}>0.05)$ indicate that there is no significant response difference among the independent sampled groups. Similarly on the in adequacy of pasture land as factor contributing for livestock deaths, median score of 4 also shows the agreement of the respondents with the factors. This indicates lack of pasture land in the borana pastoralist area is contributing for livestock death in the area. The kruskal wallis test at $(\mathrm{p}=0.035, \mathrm{df}=3$ and $\mathrm{P}<0.05)$ portray that there statistically significant response difference among the Yabello zonal Moyale, Miyo and Dire woreda. This shows similarity of leaders positive response may varies by the level of administration and place of works.

In the Table 2 concerning lack of livestock marketing as factor contributing for livestock deaths the median score of 4 shows the agreement of respondents with lack of marketing that made livestock price very low during drought. From this one can deduce that pastoralist have no willing to sell their livestock at lower price and prefer to keep until carcass. This is might emanate from remoteness of market in pastoralist area from livestock production area. The kruskal Wallis test at $(\mathrm{P}=0.351, \mathrm{df}=3$ and $\mathrm{P}>0.05)$ shows that there no statistically significant response difference among the strata. this might reveals that leaders having different level of administration and place of have no difference on considering livestock marketing as factors contributing for livestock deaths.

In the Table 2 concerning failure of traditional coping mechanism the median score 4 shows the agreement of the respondents. This indicates that traditional coping mechanism such as mobility and livestock diversification are not functioning properly. This might emanate from the expansion of arable land, inappropriate water development in pasture land, individual enclosure and tribal conflict in Borana pastoralist area. With failures of traditional coping mechanisms the results of kruskal Wallis test at $(\mathrm{p}=0.107, \mathrm{df}=3$ and $\mathrm{P}>0.05)$ indicate that there is no statically significant response difference among the groups. This means leaders having different level of administration and place of have no difference towards the above factor.

Moreover, the median score of 5 shows that respondents are agreed on the lack of awareness of the pastoralist for contribution of immense livestock deaths. From this one can depict that pastoralist have knowledge gap to made the livestock production more productive. This means that taking drought in to consideration and rescues the livestock population from deaths is held back by awareness gap. This might results of leadership failure to communicate and introduce changes in pastoralist area. Similarity of responses has no difference based on level of administration and place of work as indicated by the result of kruskal Wallis test at $(\mathrm{p}=0.170, \mathrm{df}=3$ and $\mathrm{P}>0.05)$. 
Table 3 Mann-Whitney $U$ test between zonal leaders and woreda leaders on factors contributing for livestock deaths

\begin{tabular}{|c|l|l|l|l|l|l|l|l|}
\hline \multirow{2}{*}{ Factors } & \multicolumn{2}{|l|}{ Zonal and Dire woreda } & \multicolumn{3}{l|}{ Zonal and Miyo woreda } \\
\cline { 2 - 8 } & $\begin{array}{l}\text { Mann- } \\
\text { Whitney } \\
\text { U }\end{array}$ & $\begin{array}{l}\text { Wilco } \\
\text { xon W }\end{array}$ & Z & $\begin{array}{l}\mathrm{p}- \\
\text { value } \\
(2- \\
\text { tailed) }\end{array}$ & $\begin{array}{l}\text { Mann- } \\
\text { Whitney } \\
\text { U }\end{array}$ & $\begin{array}{l}\text { Wilcoxon } \\
\text { W }\end{array}$ & Z & $\begin{array}{l}\text { p- } \\
\text { value(2- } \\
\text { tailed) }\end{array}$ \\
\hline $\begin{array}{l}\text { The resistance of } \\
\text { the pastoralist to } \\
\text { sell their } \\
\text { livestock before } \\
\text { the drought }\end{array}$ & 266.000 & 827.000 & - & 0.002 & 398.500 & 959.500 & - & 0.309 \\
\hline $\begin{array}{l}\text { Inadequacy of } \\
\text { pasture land }\end{array}$ & 460.500 & 866.500 & -.023 & .982 & 312.000 & 718.000 & - & 0.022 \\
\hline
\end{tabular}

Source: own computation, 2019

The is evidence of difference among independent sampled groups on the resistance of the pastoralist to sell their livestock before the drought and inadequacy of pasture land as factors contributing for livestock deaths at Kruskal Wallis test $(\mathrm{P}=0.013, \mathrm{df}=3$ and $\mathrm{P}<0.05$ and $(\mathrm{p}=0.035, \mathrm{df}=3$ and $\mathrm{P}<0.05)$ from Table 16 and 17 respectively. on the further inspection it was found that there is a response difference between zonal leaders and Dire woreda leaders as well as zonal leaders and Miyo woreda leaders at Mann-Whitney $U$ test $(Z=-3.172, p=0.002, P<0.05)$ and $(\mathrm{Z}=-2.286, \mathrm{p}=0.022, \mathrm{P}<0.05)$ on the resistance of pastoralist to sell their livestock before the drought and inadequacy of pasture land as contributing factor for livestock death respectively. This may mean that leaders having different level of administration have difference towards the above statement in Borana pastoralist area.

\subsection{Qualitatative Analysis}

\subsubsection{Pasture and Water}

In pastoralist area there is communal pasture land that regulated by the tradition leaders. BR001 said that "Borana give the highest value for livestock specially cattle, because cattle's are attached to the value of the Borana community. Earlier during drought and bad season's Borana follow traditional coping mechanisms. Currently because of climatic change, tribal conflicts and overgrazing there is no enough pasture land."

The above presentation reveals that the inadequacy of pasture land and water cause weakness of livestock during drought. In support of the above idea, BR002 also added that "inadequacy of pasture land, long distance travel for water (inaccessibility of water)" as factors contributing to the excessive mortality of livestock in pastoralist area. This also portrays that remoteness and scarce water source in Borana pastoralist are have relation with livestock deaths. According to researchers observation areas under ethnic conflicts such as Matawoyama, Mata-arba,Elorbi,Urgo, Siminto, kojowa,Gofa, Lehe,udat from southeastern part of Borana that are very well known for graze are restricted because of unlawful Gari tribe expansion induced conflict. Observation, FGD and document review have a consistent idea to stress that most of livestock deaths occur in search of pasture and water. This implies that inadequacy of pasture and water results with excessive mortality of livestock in pastoralist which is mainstay of the people.

\subsubsection{Livestock Disease}

The majority of the Interviewee noted that in the Borana pastoralist area most of the potential grazing land is distant from service of kebele such as animal health facilities. During drought there is a concentration of livestock population on pocket potential grazing land which very far from the center of kebele. That means most probable has single animal health posts. Especially area that considered as Golbo which considered as potential grazing land during serious drought doesn't has any animal health facilities. Discussion of most of FGD results stressed that a disease like FMD (foot and mouth disease) that hardly any to find the vaccine are the main factor contributing to livestock deaths. In addition to this there are sudden death on camel and shoats. Diseases such contagious Bovine/caprine pleuropneumonia (CCPP/CCBP), livestock skin disease (LSD), Anthrax, Diarrhea, Pests des petits (PPR), Tryps, and Bovine and ovine pasteurellosis are major causes of livestock mortality in the Borana pastoralist area.. since Borana area shares more than $521 \mathrm{~km}$ with northern Kenya, there is no strong trans-boundary disease control between both countries. From this we can deduce that lack health facility, prevention and treatment in the Pastoralist area is contributing for the loss of livestock.

\subsubsection{Attention}

In pastoralist area livestock is beyond the mainstay of community and attached to the culture of the society. Notwithstanding, we cannot find in Borana mores, rituals, folks, laws and norms a cattle as well umbilical cord of Borana's are attached it. However, as noted by majority of the interviewee less attention is given to the response for cattle in drought. In this regard, findings of FGD indicate that during drought when the animal feeds 
not affordable for government why government avail market of animal fodder, in addition to this number of deaths of animals are not disclosed for requests of intervention. This indicates that denied of attention to the pastoralist livelihood despite contribution to national economy, resulting with deterioration of livelihood in the area.

The issues discussed in the literature which noted that the warning systems have ignored the fact that livelihood of pastoralist depends on livestock (Mohammed, 2004) has a relevance with current situation in Borana pastoralist area.

\subsubsection{Awareness and Resistance of the Pastoralists}

Borana pastoralist believes in the number of herds. By the same token, in social status person who have abundant number of cattle called Duressa cicita and the poorest person called qollee. Dureessa cicita is much respected and influential in the community as well as qollee is disgraced. This determination only based on the number of livestock. To support this idea interviewee BR00 3 said that

"Awareness is key for attitudinal change, for pastoralist major asset is livestock beside that they also proud of number of their herds; they did not sell it before the period of drought.

This emanated from tie of livestock with life of the pastoralist, because for them livestock are not only asset but also moral value"

For this reason, Borana pastoralists have a resistance to sell their livestock before drought to prevent the loss. This implies that attitudinal problems and lack of awareness of pastoralist community contributing for immense livestock loss in the area which requires technical resistance management approaches to deal with it.

\subsubsection{Livestock Marketing}

Since the main income of pastoralist is livestock selling, pastoralist daily live are depends on marketing. The interviewee BR004 said that "Well I believe that there no proper market in the area. I mean that market always dominated by very few merchants from central of the country they matter only for profit and they make price of cattle at the beneath". This means there is absence of livestock at adjacent livestock production areas. In addition to this, in pastoralist area one livestock market exist at average of more than 100k.m. FGD, observation and interview finds that merchants decide the market during drought and buy livestock with very low price for fattening at Adama fattening areas at expense weak pastoralist. Pastoralist who expected the will of WAAQA prefers to keep the livestock until death to prohibit for greedy merchants. From this one can infer that absence of livestock market at adjacent area of pastoralist is contributing for death of livestock by drought.

\section{Summary}

Based on quantitative analysis and qualitative analysis findings Concerning the factors that contributing for livestock mortality both leaders and Gada fathers realized the lack of awareness of pastoralist, lack of animal health facilities, outbreak of disease, failures of early warning, inadequate pasture land, traditional coping mechanism failure, lack of livestock marketing as factors contributing to excessive livestock mortality. Their inference shows policy implementers and leadership in the area as signals for improvement of the policy implementation. Curbing capacity gaps, attitudinal barriers, and development problem as well as leadership gaps in pastoralist area are the main input to better policy implementation around pastoralist area of Ethiopia.

\section{Conclusions}

* The lives of pastoralists are depending on livestock production. Consequently, livestock's are highly attached to the totality of moral value to the people. Even though they aware of forthcoming uncertainty and changes expected from leadership, they remain unresponsive.

* Gada fathers argued that concerning the death of livestock there is an awareness gap from pastoralist. Beside the awareness of pastoralist there is also resistance of the pastoralist to sell their livestock before the drought. This is because pastoralists consider that large number of herds as an indication of status in the society.

* Regarding pasture land, in pastoralist area pasture land is communal as a property of all Borana. This communal pasture land experiencing private enclosure, inappropriate settlement in pasture land, inappropriate water development, expansion of farmland, tribal conflicts, bush encroachments and some mismanagement. On the top of this, pasture land cannot afford large numbers of livestock population. Consequently a large population of livestock would not get enough fodder from pasture land that contributing to livestock deaths.

* Concerning, animal health facility in pastoral areas, there is inadequate animal health facilities in the Borana pastoralist area. Beside this, most animal health posts are in the center of the kebeles. The centers of the kebeles are very far from the place that a large number of livestock was reared. During an outbreak of disease response and intervention is unmanageable. This adjacent animal health facility gap is contributing to the deaths of animals.

* In Borana pastoralist there is a lack of marketing. Pastoralists are travelling long distance for searching 
adjacent market. This travelling decrease the quality of livestock and the price of livestock. In addition to these middlemen are taking advantage at the expense of poor pastoralist and decide on the price. This implies that pastoralist are not benefiting from their livestock as deserved, because of absence of marketing in the pastoralist areas.

* The lives of pastoralists are depending on livestock production. Consequently, livestock's are highly attached to the totality of moral value to the people. Even though they aware of forthcoming uncertainty and changes expected from leadership, they remain unresponsive.

4 Gada fathers argued that concerning the death of livestock there is an awareness gap from pastoralist. Beside the awareness of pastoralist there is also resistance of the pastoralist to sell their livestock before the drought. This is because pastoralists consider that large number of herds as an indication of status in the society.

4 Regarding pasture land, in pastoralist area pasture land is communal as a property of all Borana. This communal pasture land experiencing private enclosure, inappropriate settlement in pasture land, inappropriate water development, expansion of farmland, tribal conflicts, bush encroachments and some mismanagement. On the top of this, pasture land cannot afford large numbers of livestock population. Consequently a large population of livestock would not get enough fodder from pasture land that contributing to livestock deaths.

* Concerning, animal health facility in pastoral areas, there is inadequate animal health facilities in the Borana pastoralist area. Beside this, most animal health posts are in the center of the kebeles. The centers of the kebeles are very far from the place that a large number of livestock was reared. In addition to this most of the health post are not equipped and out of animal health technicians. During an outbreak of disease response and intervention is unmanageable. This adjacent animal health facility gap is contributing to the deaths of animals.

* In Borana pastoralist there is a lack of marketing. Pastoralists are travelling long distance for searching adjacent market. This travelling decrease the quality of livestock and the price of livestock. In addition to these middlemen are taking advantage at the expense of poor pastoralist and decide on the price. This implies that pastoralist are not benefiting from their livestock as deserved, because of absence of marketing in the pastoralist areas.

\section{Recommendation}

4 Drought risk management is policy issues that seek coordination at apex of authority. So, the federal government of Ethiopia should coordinate different stakeholders and multiagency at national level. Most of the time policy due attention for problems arise around the highland agrarian community than lowland pastoralist. So it's imperative to give special emphasis to pastoralist area. Policy implementers advised to ensure participation pastoralist community in advance.

\# Leadership in the area should be alert especially on the prevention of diseases by implementing possible animal health extension service. Since great role of leadership is coordinating different stakeholders, leaders should coordinate the resource in the hand of government and non-governmental organization (NGO) for betterment of livestock production and health in the pastoralist area.

- Attitudinal barriers are hampering the system making meaning. Creation of awareness for woreda leaders, community and other stakeholder to challenge the current status quo in Borana pastoralist is very decisive. Especially the attitude of believing in large herds by ignoring the quality of livestock production and resistance to sell their livestock before drought should be attentively communicated.

* Government should able to create strong institution such as Diagnostic laboratory in Borana zone in order to control the disease outbreak and delivery proper vaccinations. This may improve the control of sudden death that seen on camel and shoats. Government should also trace the livestock mobility root and avail livestock health facilities. Ethiopian and Kenyan Government should work together to control trans-boundary disease between Borana zone and Marsabit county.

* Borana pastoralists have experience of managing multiple crises in the Gada system before many centuries. So this institution is very important opportunity to manage drought disaster in line with strengthening existing traditional coping mechanism such as mobility, selling livestock before the drought, diversification of herds, strengthen of communal pasture land management, decrease illegal settlement on pasture land, enhance participation pastoralist in every development activity and identify potential grazing land. Beside this government also should implement strategic and viable integrated natural resource management system.

\# In addition to this, the pastoralist community should draw a lesson from the mistake of the past and implement lesson that is learned from drought impacts which is decidedly vivid in the area, like livestock loss because of the resistance to the sell the livestock before drought and save the money in the adjacent saving and credit association, cooperative, banks and transfer it to another ex-pastoralist 
livelihood.

* Generally excessive death of livestock in Borana pastoralist area is strong signal for leadership in the area and status of implementation of Disaster Risk Management Policy of Ethiopia. Policy implementers should rethink on conflict management, rangeland management system, early warning systems, disease prevention and control system, livestock marketing and value chain management, community participation, and strategic planning in the pastoralist area. The future researchers should also focus on the aforementioned policy design and implementation gaps in the pastoralist area.

\section{References}

Angassa, A. and Oba, G. (2007) Relating long-term rainfall variability to cattle population dynamics in communal rangelands and a government ranch in southern Ethiopia, Agricultural Systems, 94, 715-175.

Legessee, A. (1973) Gada: Three Approach to Study African Society.Michigan: Free press.

Borana Zonal Finance and Economic Development office (2019) Annual Report, Yabello: Unpublished.

Beruk, Y. (2003) Food Security Situation in the Pastoral Areas of Ethiopia, Addis Ababa. Available at: https://www.tandfonline.com/doi/abs/10.1080/17531050903556709 (Accessed: 21 December 2019).

Catley, A., Berhanu, A.,Gezu,B., \& Dawit, A.(2014) 'Impact of drought-related livestock vaccination in pastoralist areas of Ethiopia'. Disasters 38(3), 500-516.

Dika Godana G.(2016) The Role of Indigeniuos Knowledge in Rangeland Management in Yabello Woreda,Southern Oromia,Ethiopia. Arts social Sci j7:172.doi:10.4172/2151-6200.1000172.

FAO(1995) Draft country information brief, Ethiopia. Available at: www.fao.org/countryprofiles/index/en/?iso3=eth Accessed on (December 20, 2019).

Mohammed Mussa (2004) A comparative Study of Pastoralist Parliamentary Groups: A Case Study on Pastoral Affairs standing committee of Ethiopia. Addis Ababa,Ethiopia.

Marko, L. (2012) Drought Contingency Plans and Planning in the Greater Horn of Africa: A Desktop Review of the Effectiveness of Drought Contingency Plans and Planning in Kenya, Uganda and Ethiopia, UNON. Nairobi: publishing services section.

Pastoralist Area Development Commission (2019), Strategic Plan, Finfinne: Unpublished.

Solomon, D., Wassie B., Getachew G. \& Dadhi A. (2008) Pastoralist Dropout Study in Selected woredas of Borena Zone Oromia Regional State. Available at: www.prime-ethiopia.org/wp-content/upload (Accessed: 27 February 2019).

1. Petros Wako Halake has BA in Sociology, MA in Leadership and Good Governance, MBA in Project Management, PhD candidate at Huazhong University of Science and Technology, School of Public Adminstration, Departemt of Adminstrative Management.

2. Neng Shen is PhD in Management and Engineering, Professor at Huazhong University of Science and Technology, School of Public Administration, Department of Administrative Management. 